\title{
The Impact of Technological Advancement on Digital Addiction Level of Youth in India
}

\author{
Aditi Mittal, Nitin Bansal
}

\begin{abstract}
As India is overrunning towards digitalization, and along with showing technological advancements and conveniences, it has also presented some unfortunate consequences for the youth. This research paper focuses on the serious concern of negative effects of technology on the teenagers and youngsters of the country. The researcher has attempted to identify the various factors having influence on youth's digital addiction level and also analysis the impact of demographic variables on it. The study has been conducted through the structured questionnaire rolling among the people of different age groups to analyse the perception of the different occupation on the addiction level of the youth. With the sample size of 405 people, the finding has uncovered the facts of addiction level, and the mess between the youth and overuse of gadget. The results also suggest how the parents can tackle with the negative effects of technology for the well-being of their children. Key Words: Addiction, Digitalization, Technology.
\end{abstract}

\section{INTRODUCTION}

The effect of the internet on individual's social participation and well-being shows that more you use the internet less you communicate with family members and this will lessen the social circles [20]. Working on Internet can reduce interpersonal interaction and communication. Further, it is pointed out that the socially isolated teenagers are more likely to use the Internet $[24,26]$. Quick and easy access to the needed information has also reduced the creativity of the students and bullying using the internet facility is the evilest effect of the internet. The study conducted by Stanford University on internet usage showed that $12.4 \%$ of participants stayed online for a longer time than they intended very often. It is found that excessive electronic media use at night disturbs the sleep which develops the depression [23].

\section{REVIEW OF LITERATURE}

The survey on 319 university students consisting of 203 females and 116 males analysed that the problem of depression, anxiety, which turns into sleep problems is over usage of the smartphone [6]. The continuous decline in the price of the digital device evince that the use of the smartphone has also increased [15] and this immense usage affects the physical condition of an individual such as suffering from pain in neck and wrist [21].

Revised Manuscript Received on October 31, 2019

* Correspondence Author

Dr. Aditi Mittal*, SBI School of Commerce and Banking, Banasthali Vidyapith, Tonk, Rajsathan, India. Email: aditimittal7@gmail.com

Mr. Nitin Bansal, SBI School of Commerce and Banking, Banasthali

Vidyapith, Tonk, Rajsathan, India.. Email:bansal.nitin@ @rediffmail.com
In the present time the usage of digital devices for banking functions, have also been increased among different age groups of users [2]. Mostly youth use the digital functions for digital transactions and now people avoid visiting the bank branches and interacting with bank officials regularly. Users often operate mobile with a single hand, which coerce only the thumb to use the smartphone [37] and it has been surveyed that the university students spend more than 3.5 hour/day on an average for texting, scheduling, emailing and internet browsing and they usually feel pain in thumb [4]. Teenagers generally use their smartphone to chat on social networking sites, for sharing their personal information, for uploading the images, videos etc. They update their personal mobile number, email id on social networking sites without contemplating the privacy rules and concerning about the hacking, or threat of misusing of their information by the unknown. Teenagers also access pornographic sites from their smartphone. Sometimes, misuse of smartphone involves the students in illegal activity of cheating during examinations. Teenage boys spend the longest time, with an average of eight hour/day. Teenagers who use internet on a regular basis or always be online on social networking sites, suffer from psychological issues such as aggressiveness, paranoia, mania, narcissism, and shows antisocial behavior. The anecdotal report on addiction level showed that addiction of internet is same as addiction of alcohol, or drugs, and it affects the social, academic, occupational impairment [38]. However, some of the researches of psychiatrists, psychologists and sociologists, has not recognized addictive usage of the technology as a problematic conduct. One of the study analysed the fact of Internet addiction and the level of difficulty faced by such potential misuse. IT is also found that in the Diagnostic and Statistical Manual of Mental Disorders-Fourth Edition, Pathological Gambling was considered similar to the pathological nature of technology utilization. With the help of the model of Pathological Gambling, the addictive use of Internet can be described as an impulse-control disorder which does not includes an intoxicant [12].

In the qualitative research of functional and behavioral usage of technology, it is noted that there is significant difference between the two groups in respect to the type of applications utilized, the level of problem controlling weekly usage, and the extremity of problems noted. Clinical and communitybased implications on pathological Internet use and future conduct for investigation are explored.

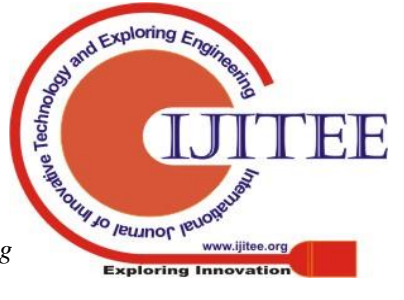




\section{The Impact of Technological Advancement on Digital Addiction Level of Youth in India}

The research has also focused on the treatment protocol for the people having the problem of related to a pathological Internet use [39]. Sound management of psychiatric symptoms can indirectly cure pathological Internet use. Unreasonable usage of internet indicates that people are using internet as a tool for the unproductive activities like to be in a relationship [11]. However, internet addiction may be prevalent in a significant minority of individuals. Internet addiction has been correlated with dimensionally studied depression and measures of social isolation [34]. Psychiatric co-morbidity is common, particularly anxiety, impulse control, mood, and substance use disorders. Aetiology is unknown, but probably includes neurobiological, psychological, and cultural factors. It is analysed in the context of youth's online risky activities, whether the compensatory-competition model or the continuity-cognitive model prevails and explored whether the engagement of parental mediation activities mitigates or compounds the situation [36]. A study related to bank and observed that now most of the customers prefer to operate the banking transactions through online modes and now people are habitual to use to advanced technological devices for performing financial transactions which is easy to perform [3]. So we can say that people are now going to be addictive of digital devices to save their time and other resources. The research of Malaysian school showed that for the teenagers of age group 13 - 15 years, peer-attachment plays an important role than parent attachment in risky online activities and Internet addiction. However, when parents themselves get involved in teenagers online activities then it influence them in using the digital gadget safely. This concludes that parents have more impact on teenagers than their friends. In the analysis of relationship between Internet addiction and social support in China with a meta-analysis of 76 articles consist of 47,899 teenagers and young adults, it is observed that there is medium-sized negative correlation between Internet addiction and social support. Moreover, this medium-sized correlation varies with respect to demographic variables. However this negative link was smaller when calculating Internet addiction with the Internet Addiction Test (IAT) than when using other measures. The results have also showed that for males there is more negative link between Internet addiction and social support. The size of the negative correlation coefficient was largest in Eastern China, smaller in Central China, and smallest in Western China [22]. With the rapid development of science and technology, and better living standard of people, Internet having features of low cost, large information source and rapid speed, plays an important role in common people's life. Along with lot of advantages of the use Internet, it has also brought a lot series of social problems. Under the new situation, teen Internet addiction index is getting higher and higher [40]. Research carried among German and Chinese college students on the relation between the depression and Internet Use Disorder (IUD) described that depression is related with IUD in both the cases [30]. Harmful results of the internet unproductive usage are generalized internet addiction, online gambling addiction and online gaming addiction [9]. Similarly, survey conducted on British children and adolescents observed that there are three aspects of problematic internet use (PIU) i.e. Obsession, Neglect and Control Disorder. PIU is significantly associated with the hyperactivity, depressive, conduct disorder, physical health, and daily routine. Additionally, males have higher PIU then females, especially obsession [8]. Loneliness is another factor of how people are using digital platform or the way of getting addicted. People find this as a medium of being socialize, form interpersonal relations and to bring down their loneliness [27].

\section{A. Research Gap}

As India is moving towards digitalization and has become the fastest economy of the world. Along with the ongoing success of providing user friendly digital platform, there are some adverse effects of using the technology which the people knowingly neglect. Using the internet for longer time with no reason states that people are getting addicted to the digital devices. It is evident that many researchers has tried to find out the addiction level of the people, mostly outside India, but very few researches has focused on measuring youth's addiction level and identifying the various factors having influence on it, in India, where the digital literacy is near to no-existent.

\section{B. Relevance of the Study}

The study is important to get an attention of an individual, a group and the government on the negative effects of the technology which the people generally ignore. Everyone is trying to get digitalize and the government is also focusing on making the people of India digital literate but digital literacy is not only about the knowledge of using the digital device, but also not getting addicted of the technology is the core part of digital literacy. The problem of internet addiction should be focused in the initial stage of one getting digital literacy either by any of the family member or by the institution. Providing digital literacy using "Bhartiya Model of Digital Literacy" can be a good option to protect people from addiction because this definition is comprises of all the aspects of the digital literacy which shields the people from it. Considering this issue, the research finds out the current statistics on the addiction level of youth in India on the basis of the socio-economic factors. The study also gives the recommendation especially to the parents on how they can protect their children of any of the age from this hazardous drug.

\section{Objectives}

1. To measure the addiction level of youth on the basis of educational qualification and gender.

2. To understand the perception of the adults on addiction level of the youth.

3. To identify the various factors having influence on youths addiction level.

4. To analyze the impact of technological advancement on the addiction level of youth. Blue Eyes Intelligence Engineering

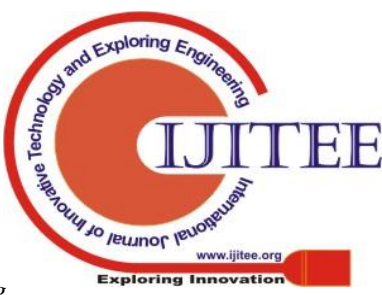

\& Sciences Publication 


\section{Hypotheses}

To check the impact of technological advancement on addiction level of youth the researcher has formed following hypotheses:-

i. $\mathrm{H}_{01}$ - There is no significant impact of duration to stay online on the addiction level of youth in India.

ii. $\mathrm{H}_{02^{-}}$There is no significant impact of excitement level of youth on the addiction level of youth in India.

iii. $\mathrm{H}_{03}-$ There is no significant impact of anticipation while going online again of youth on the addiction level of youth in India.

iv. $\mathrm{H}_{04^{-}}$There is no significant impact of life without internet on the addiction level of youth in India.

v. $\mathrm{H}_{05^{-}}$There is no significant impact of feeling of user being offline on the addiction level of youth in India.

\section{RESEARCH METHODOLOGY}

This is exploratory research where data has been collected from the primary sources. The questionnaire of Internet Addiction Test (IAT) constructed by Dr. Kimberly Young has been used and modified as per the social economic constraints of Indian market and circulated to 450 people of different age groups. Out of 450 distributed questionnaires, 405 useful questionnaires have been received. The sample of 405 has been taken into consideration for the authenticity of the results and respondents have been chosen using stratified random sampling. The results have been analysed with the help of SPSS software version 23 using statistical tool like factor analysis and multiple regression (Stepwise forward selection).

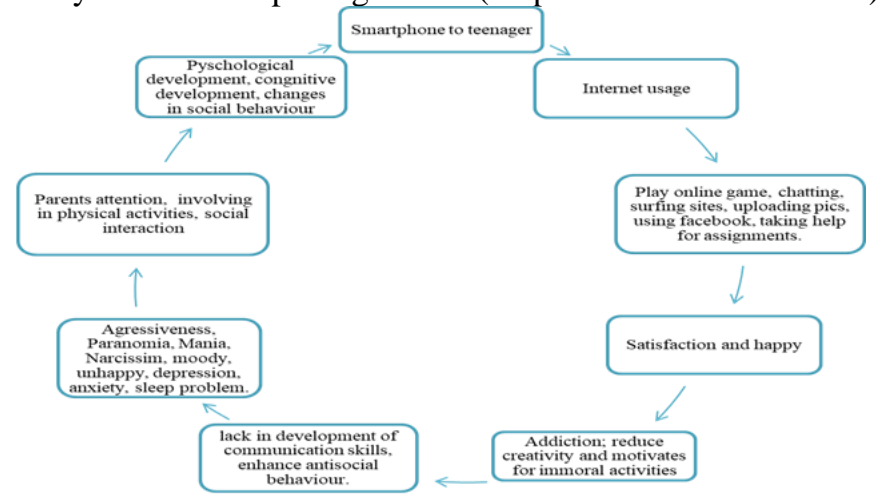

Fig. 1 Cycle of Addiction

\section{ANALYSIS AND INTERPRETATION}

\section{A. Cycle of Addiction}

On the basis of extensive literature review, researcher has prepared addiction cycle (Figure 1) to digital gadgets which shows how the teenager get influence to smartphone, how they misuse the gadgets, what problems they face, what are the circumstances of over usage and finally recommendations for the parents.

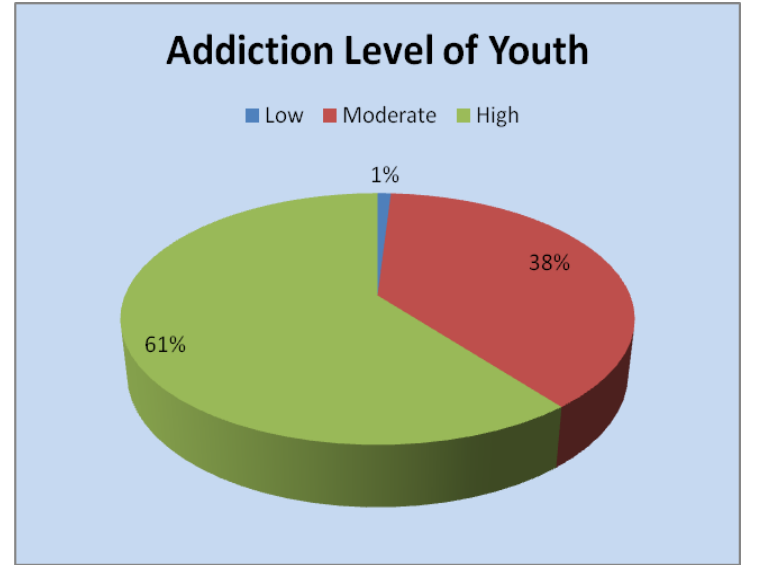

Fig. 2 Pie-Chart representing addiction level of youth

\section{A. Addiction Level of Youth}

The above pie chart evidently exhibits that $1 \%$ respondents were low addicted, $38 \%$ moderate addicted and $61 \%$ youth was highly addicted to the digital gadgets. This shows that more that $60 \%$ of the total sample was addicted.

\section{B. Addiction Level of Youth with their Educational Qualification}

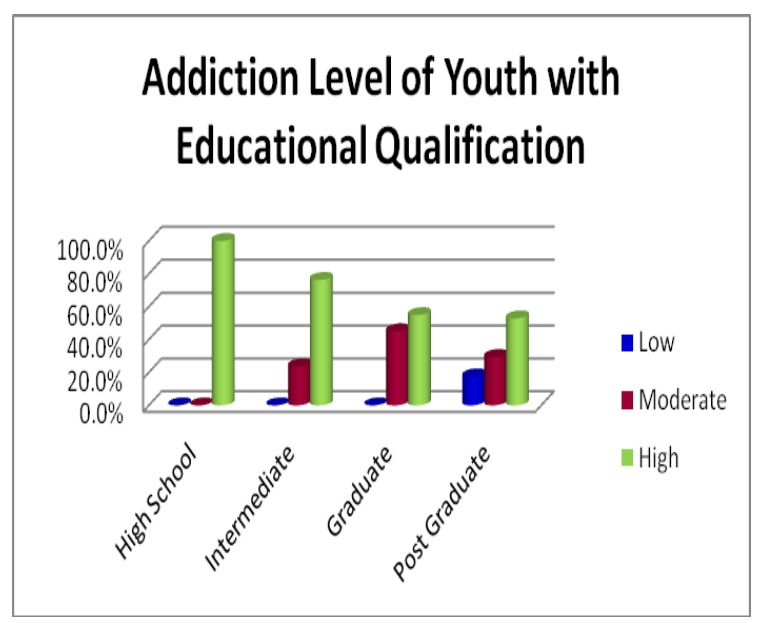

Fig. 3 Bar-Chart representing addiction level of youth with educational qualification

The above bar graph shows that students of High School have more addiction level than all other educational qualification. With little less percentage is intermediate, graduate and post graduate.

\section{Addiction Level of Youth with Gender}


The Impact of Technological Advancement on Digital Addiction Level of Youth in India

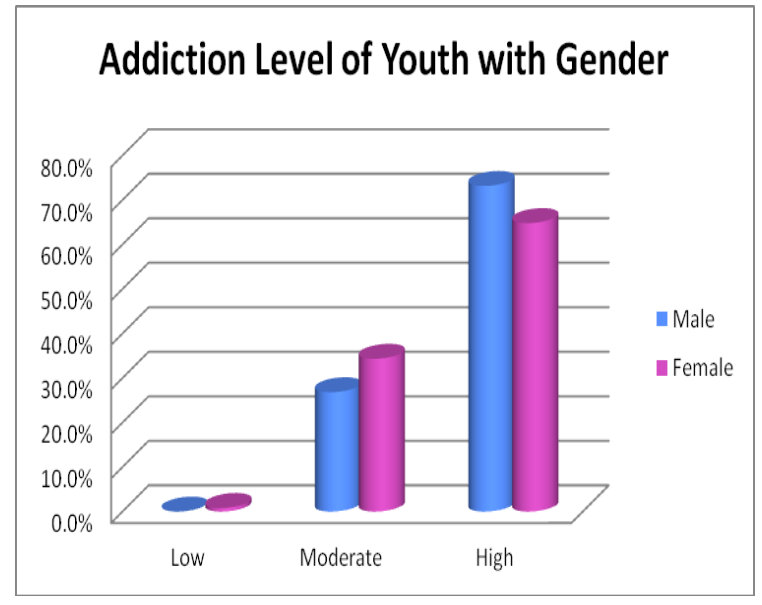

Fig. 4 representing bar-graph of Addiction level of youth with gender

Fig. 4 clearly depicts that Male are more highly addicted than Females.

\section{Perception of Adults for Youth Addiction \\ E. Variables Coding for Technological Advancement on Digital Addiction Level of Youth.}

\begin{tabular}{|l|c|c|}
\hline Variable Details & $\begin{array}{c}\text { Varia } \\
\text { ble }\end{array}$ & Nature \\
\hline Duration of stay online & D1 & Dependent \\
\hline $\begin{array}{l}\text { Cut down the online } \\
\text { stay time ID11 } \\
\text { Independent }\end{array}$ & ID11 & Independent \\
\hline Hide your online stay & ID12 & Independent \\
\hline Time online going out & ID13 & Independent \\
\hline
\end{tabular}

\begin{tabular}{|l|c|c|}
$\begin{array}{l}\text { Emotions while off } \\
\text { line }\end{array}$ & ID14 & Independent \\
\hline Emotions while online & ID15 & Independent \\
\hline Excitement of internet & D2 & Dependent \\
\hline $\begin{array}{l}\text { Relationships with } \\
\text { fellow users ID21 } \\
\text { Independent }\end{array}$ & ID21 & Independent \\
\hline Impact of productivity & ID22 & Independent \\
\hline Defensive behavior & ID23 & Independent \\
\hline $\begin{array}{l}\text { Anticipation while } \\
\text { going online D3 } \\
\text { Dependent }\end{array}$ & D3 & Dependent \\
\hline $\begin{array}{l}\text { Stretching your online } \\
\text { stay ID31 } \\
\text { Independent }\end{array}$ & ID31 & Independent \\
\hline Unsound sleep & ID32 & Independent \\
\hline $\begin{array}{l}\text { Impact on school work } \\
\text { ID33 Independent }\end{array}$ & ID33 & Independent \\
\hline $\begin{array}{l}\text { Life without internet } \\
\text { D4 Dependent }\end{array}$ & D4 & Dependent \\
\hline
\end{tabular}

\begin{tabular}{|l|c|c|}
$\begin{array}{l}\text { Neglect household } \\
\text { chores ID41 } \\
\text { Independent }\end{array}$ & ID41 & Independent \\
\hline $\begin{array}{l}\text { Complaints from } \\
\text { others }\end{array}$ & ID42 & Independent \\
\hline $\begin{array}{l}\text { Preoccupied while } \\
\text { offline D5 } \\
\text { Dependent }\end{array}$ & D5 & Dependent \\
\hline Checking emails & ID51 & Independent \\
\hline $\begin{array}{l}\text { Controlling emotions } \\
\text { ID52 Independent }\end{array}$ & ID52 & Independent \\
\hline
\end{tabular}

\section{F. Normality}

\begin{tabular}{|c|c|c|c|c|}
\hline \multicolumn{5}{|c|}{ Descriptive Statistics } \\
\hline & $\mathrm{N}$ & Mean & $\begin{array}{c}\text { Skewnes } \\
\text { s }\end{array}$ & Kurtosis \\
\hline & $\begin{array}{c}\text { Statisti } \\
\mathrm{c}\end{array}$ & Statistic & Statistic & Statistic \\
\hline D1 & 405 & 4.37 & -1.511 & 1.362 \\
\hline ID11 & 405 & 3.72 & -0.451 & -0.242 \\
\hline ID12 & 405 & 3.9 & -0.799 & 0.257 \\
\hline ID13 & 405 & 3.79 & -0.6 & -0.341 \\
\hline ID14 & 405 & 3.58 & -0.554 & -0.152 \\
\hline ID15 & 405 & 3.76 & -0.702 & -0.062 \\
\hline D2 & 405 & 3.1 & 0.397 & 0.095 \\
\hline ID21 & 405 & 3.74 & -1.531 & 4.436 \\
\hline ID22 & 405 & 3.51 & -0.413 & -0.42 \\
\hline ID23 & 405 & 3.81 & -0.547 & -0.052 \\
\hline D3 & 405 & 4.05 & -1.534 & 1.498 \\
\hline ID31 & 405 & 4.14 & -0.622 & 1.011 \\
\hline ID32 & 405 & 4.36 & -0.629 & 0.338 \\
\hline ID33 & 405 & 4.05 & -1.534 & 3.498 \\
\hline D4 & 405 & 3.27 & -0.047 & -0.945 \\
\hline ID41 & 405 & 3.96 & -1.239 & 0.432 \\
\hline ID42 & 405 & 3.91 & -0.9 & -0.287 \\
\hline D5 & 405 & 3.66 & -0.509 & 0 \\
\hline ID51 & 405 & 3.27 & -0.047 & -0.945 \\
\hline ID52 & 405 & 3.64 & -0.649 & 0.258 \\
\hline $\begin{array}{l}\text { Valid } \\
\mathrm{N} \\
\text { (listwi } \\
\text { se) } \\
\end{array}$ & 405 & & & \\
\hline
\end{tabular}

\section{Published By:}

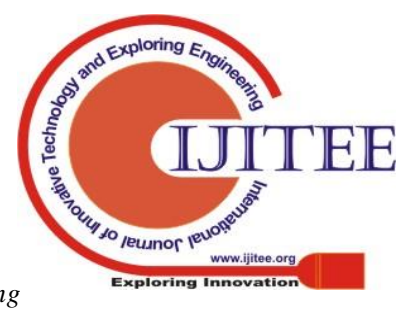




\section{G. Factor Analysis}

i. KMO and Bartlett's Test

\begin{tabular}{|l|l|r|}
\hline \multicolumn{2}{|l|}{$\begin{array}{l}\text { Kaiser-Meyer-Olkin Measure of } \\
\text { Sampling Adequacy. }\end{array}$} & 0.822 \\
\hline \multirow{3}{*}{$\begin{array}{l}\text { Bartlett's Test of } \\
\text { Sphericity }\end{array}$} & $\begin{array}{l}\text { Approx. } \\
\text { Chi- } \\
\text { Square }\end{array}$ & 1173.663 \\
\cline { 2 - 3 } & df & 66 \\
\cline { 2 - 3 } & Sig. & 0 \\
\hline
\end{tabular}

\section{ii. Communalities}

\begin{tabular}{|c|c|c|}
\hline \multicolumn{3}{|c|}{ Communalities } \\
\hline & Initial & Extraction \\
\hline ID11 & 1 & 0.671 \\
\hline ID12 & 1 & 0.604 \\
\hline ID13 & 1 & 0.522 \\
\hline ID14 & 1 & 0.536 \\
\hline ID15 & 1 & 0.514 \\
\hline ID22 & 1 & 0.658 \\
\hline ID23 & 1 & 0.645 \\
\hline ID31 & 1 & 0.484 \\
\hline ID32 & 1 & 0.514 \\
\hline ID41 & 1 & 0.684 \\
\hline ID42 & 1 & 0.787 \\
\hline ID51 & 1 & 0.682 \\
\hline ID52 & 1 & 0.662 \\
\hline Extraction Method: Principal \\
Component Analysis. \\
\hline \multicolumn{3}{|c|}{} \\
\hline
\end{tabular}

iii. Rotated Component Matrix

\begin{tabular}{|c|c|c|c|c|}
\hline \multicolumn{5}{|c|}{ Rotated Component Matrix ${ }^{\mathrm{a}}$} \\
\hline \multirow{2}{*}{} & \multicolumn{5}{|c|}{ Component } \\
\cline { 2 - 5 } & 1 & 2 & 3 & 4 \\
\hline ID11 & 0.769 & & & \\
\hline ID12 & 0.741 & & & \\
\hline ID13 & 0.646 & & & \\
\hline ID14 & 0.662 & & & \\
\hline
\end{tabular}

\begin{tabular}{|l|l|l|l|l|} 
ID15 & 0.691 & & & \\
\hline ID22 & & 0.795 & & \\
\hline ID23 & & 0.714 & & \\
\hline ID31 & 0.439 & & & \\
\hline ID32 & 0.505 & & & \\
\hline ID41 & & & & 0.954 \\
\hline ID42 & & & & 0.878 \\
\hline ID51 & & & 0.818 & \\
\hline
\end{tabular}

\begin{tabular}{|l|l|}
\hline ID52 & 0.711 \\
\hline Extraction Method: Principal Component Analysis. \\
\hline Rotation Method: Varimax with Kaiser Normalization. \\
\hline a. Rotation converged in 6 iterations. \\
\hline
\end{tabular}

\section{Perception of Adults on Addiction Level of Youth \\ Low Moderate High}

$1 \%$

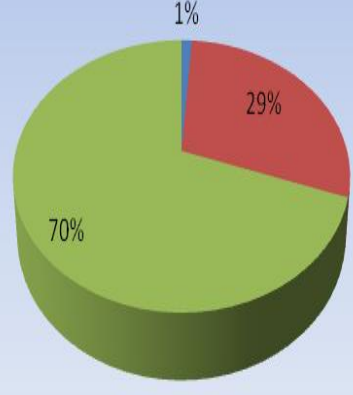

Fig. 5 representing pie-chart of perception of adults on addiction level of youth

The adult's perception for the addiction level of youth is they think that only $1 \%$ of respondents are low addicted, $29 \%$ moderate addicted and $70 \%$ are highly addicted to the digital gadgets.

\section{H. Reliability Analysis}

\begin{tabular}{|c|c|c|}
\hline $\begin{array}{c}\text { Variables/combined } \\
\text { items }\end{array}$ & Anchor & $\begin{array}{c}\text { Cronbach's } \\
\alpha\end{array}$ \\
\hline 1 & 7 & 0.808 \\
\hline 2 & 2 & 0.759 \\
\hline 3 & 2 & 0.742 \\
\hline 4 & 2 & 0.799 \\
\hline
\end{tabular}

\section{J. Multiple Regression Analysis}

i. $\quad$ Model Summary ${ }^{e}$

\begin{tabular}{|c|c|c|c|}
\hline Model & $\mathrm{R}$ & R Square & $\begin{array}{c}\text { Adjusted } \\
\text { R Square }\end{array}$ \\
\hline 1 & $.643^{\mathrm{a}}$ & 0.597 & 0.595 \\
\hline 2 & $.922^{\mathrm{b}}$ & 0.853 & 0.85 \\
\hline 3 & $.716^{\mathrm{c}}$ & 0.611 & 0.608 \\
\hline 4 & $.883^{\mathrm{d}}$ & 0.734 & 0.732 \\
\hline
\end{tabular}




\section{The Impact of Technological Advancement on Digital Addiction Level of Youth in India}

\begin{tabular}{|l|}
\hline a. Predictors: (Constant), $\mathrm{ID}_{11}, \mathrm{ID}_{12}, \mathrm{ID}_{13}, \mathrm{ID}_{14}$, \\
$\mathrm{ID}_{15}, \mathrm{ID}_{31}, \mathrm{ID}_{32}$ \\
\hline b. Predictors: (Constant), $\mathrm{ID}_{22}, \mathrm{ID}_{23}$ \\
\hline c. Predictors: (Constant), $\mathrm{ID}_{51}, \mathrm{ID}_{52}$ \\
\hline d. Predictors: (Constant), $\mathrm{ID}_{41}, \mathrm{ID}_{42}$ \\
\hline d. Dependent Variable: $\mathrm{D}_{1}$ for Model $1, \mathrm{D}_{2}$ for \\
Model $2, \mathrm{D}_{5}$ for Model 3 and $\mathrm{D}_{4}$ for Model 4 \\
\hline
\end{tabular}

\section{ii. $\quad$ ANOVA}

\begin{tabular}{|c|c|c|c|c|c|c|}
\hline $\begin{array}{l}\text { Mode } \\
l\end{array}$ & & $\begin{array}{l}\text { Sum } \\
\text { of } \\
\text { Squar } \\
\text { es }\end{array}$ & $d f$ & $\begin{array}{l}\text { Mea } \\
n \\
\text { Squa } \\
\text { re }\end{array}$ & $F$ & $\begin{array}{l}S i \\
g .\end{array}$ \\
\hline \multirow[t]{3}{*}{1} & $\begin{array}{l}\text { Regres } \\
\text { sion }\end{array}$ & 168.45 & 7 & 54.21 & 107.59 & $\begin{array}{c}.00 \\
0^{\mathrm{b}} \\
\end{array}$ \\
\hline & $\begin{array}{l}\text { Residu } \\
\text { al }\end{array}$ & 132.04 & 398 & 0.326 & & \\
\hline & Total & 300.49 & 405 & & & \\
\hline \multirow[t]{3}{*}{2} & $\begin{array}{l}\text { Regres } \\
\text { sion }\end{array}$ & 468.32 & 2 & 159.32 & 327.58 & $\begin{array}{c}.00 \\
0^{\mathrm{c}}\end{array}$ \\
\hline & $\begin{array}{l}\text { Residu } \\
\text { al }\end{array}$ & 162.07 & 403 & 0.32 & & \\
\hline & Total & 630.39 & 405 & & & \\
\hline \multirow[t]{3}{*}{3} & $\begin{array}{l}\text { Regres } \\
\text { sion }\end{array}$ & 394.24 & 2 & 202.48 & 177.63 & $\begin{array}{c}.00 \\
0^{\mathrm{d}}\end{array}$ \\
\hline & $\begin{array}{l}\text { Residu } \\
\text { al }\end{array}$ & 166.25 & 403 & 0.59 & & \\
\hline & Total & 560.49 & 405 & & & \\
\hline \multirow[t]{3}{*}{4} & $\begin{array}{l}\text { Regres } \\
\text { sion }\end{array}$ & 398.21 & 2 & 259.61 & 206.21 & $\begin{array}{c}.00 \\
0^{\mathrm{e}}\end{array}$ \\
\hline & $\begin{array}{l}\text { Residu } \\
\text { al }\end{array}$ & 199.03 & 403 & 0.25 & & \\
\hline & Total & 597.24 & 405 & & & \\
\hline \multicolumn{7}{|c|}{$\begin{array}{l}\text { a. Dependent Variable: } \mathrm{D}_{1} \text { for Model } 1, \mathrm{D}_{2} \text { for Model } 2, \mathrm{D}_{5} \text { for } \\
\text { Model } 3 \text { and } \mathrm{D}_{4} \text { for Model } 4\end{array}$} \\
\hline \multicolumn{7}{|c|}{ b. Predictors: (Constant), ID $\mathrm{ID}_{11} \mathrm{ID}_{12}, \mathrm{ID}_{13}, \mathrm{ID}_{14}, \mathrm{ID}_{15}, \mathrm{ID}_{31}, \mathrm{ID}_{32}$} \\
\hline \multicolumn{7}{|c|}{ c. Predictors: (Constant), $\mathrm{ID}_{22}, \mathrm{ID}_{23}$} \\
\hline \multicolumn{7}{|c|}{ d. Predictors: (Constant), $\mathrm{ID}_{51}, \mathrm{ID}_{52}$} \\
\hline \multicolumn{7}{|c|}{ e. Predictors: (Constant), $\mathrm{ID}_{41}, \mathrm{ID}_{42}$} \\
\hline
\end{tabular}

\section{iii. Coefficients ${ }^{a}$}

\begin{tabular}{|c|c|c|c|c|c|}
\hline Model & \multicolumn{2}{|c|}{$\begin{array}{c}\text { Unstandardized } \\
\text { coefficients }\end{array}$} & $\begin{array}{c}\text { Standar } \\
\text { dized } \\
\text { coeffici } \\
\text { ents }\end{array}$ & & \\
\hline & $B$ & $\begin{array}{c}\text { Std.Err } \\
\text { or }\end{array}$ & Beta & $t$ & Sig. \\
\hline $\begin{array}{c}\text { (Consta } \\
\text { nt })\end{array}$ & 0.548 & 0.0124 & & 3.547 & 0.00 \\
\hline ID 11 & 0.26 & 0.045 & 0.29 & 6.215 & 0.00 \\
\hline ID12 & 0.31 & 0.024 & 0.32 & 3.024 & 0.00 \\
\hline ID13 & 0.21 & 0.027 & 0.62 & 2.457 & 0.00 \\
\hline ID14 & 0.62 & 0.065 & 0.34 & 3.548 & 0.00 \\
\hline ID15 & 0.29 & 0.084 & 0.49 & 4.218 & 0.00 \\
\hline ID31 & 0.15 & 0.091 & 0.18 & 4.358 & 0.00 \\
\hline
\end{tabular}

\begin{tabular}{|c|c|c|c|c|c|}
\hline ID32 & 0.14 & 0.005 & 0.76 & 3.982 & 0.00 \\
\hline $\begin{array}{c}2 \\
\text { (Consta } \\
\text { nt) }\end{array}$ & -0.26 & 0.201 & & -2.658 & 0.00 \\
\hline ID22 & 0.258 & 0.068 & 0.39 & 7.524 & 0.00 \\
\hline ID23 & 0.547 & 0.079 & 0.648 & 9.524 & 0.00 \\
\hline $\begin{array}{c}3 \\
\text { (Consta } \\
\text { nt) }\end{array}$ & 0.698 & 0.249 & & 1.268 & 0.00 \\
\hline ID51 & 0.257 & 0.057 & 0.548 & 5.248 & 0.00 \\
\hline ID52 & 0.584 & 0.069 & 0.624 & 7.951 & 0.00 \\
\hline $\begin{array}{c}4 \\
\text { (Consta } \\
\text { nt) }\end{array}$ & 0.797 & 0.124 & & 2.524 & 0.00 \\
\hline ID41 & 0.584 & 0.098 & 0.624 & 6.298 & 0.00 \\
\hline ID42 & 0.249 & 0.027 & 0.841 & 7.521 & 0.00 \\
\hline \multicolumn{6}{|c|}{$\begin{array}{l}\text { a. Dependent Variable: } \mathrm{D}_{1} \text { for Model } 1, \mathrm{D}_{2} \text { for Model 2, } \mathrm{D}_{5} \text { for } \\
\text { Model } 3 \text { and } \mathrm{D}_{4} \text { for Model } 4\end{array}$} \\
\hline
\end{tabular}

\section{Excluded Variables}

$\mathrm{ID}_{21}$ and $\mathrm{ID}_{33}$ have been excluded from the analysis as both these variables have kurtosis value more than 2 which is not acceptance, so excluded.

\section{FINDINGS}

All the hypotheses were tested with the help of multiple regression and results revealed that the significance value is less than 0.05 which is acceptable. So we reject the null hypotheses and accept the alternate hypotheses i.e. $\mathrm{H}_{\mathrm{al}}, \mathrm{H}_{\mathrm{a} 2}$, $\mathrm{H}_{\mathrm{a} 3}, \mathrm{H}_{\mathrm{a} 4}$ and $\mathrm{H}_{\mathrm{a} 5}$.

\section{CONCLUSION}

The main reasons of being lean on technology are sense of satisfaction and belief of feeling happy over facebook, online video games, chatting etc. [19]. To overcome all these negative effects of technology, the parents needs to monitor the children on an regular basis when they use digital gadgets although it is little difficult for the parent to monitor the child all the time because nowadays, digitalization in schools, colleges has made the children to use technology for not only doing the online uploaded homework but also for tracking the progress in a class, for taking help of internet to prepare project or for doing assignments. So children make good excuse for using technology to their parents.

For continuous monitoring of child, one thing that a parent can do is allowing him/her in public place of home rather than allowing them to use in their own room. Parents also need to get the time to involve themselves in the activities of their children.

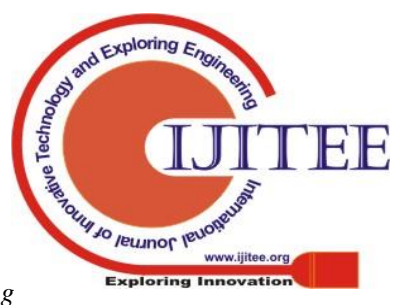


Playing games with the children will positively impact their physical, cognitive, psychological development. Parents should also make the child social and make them face the society. Doing this frequently will make a child to overcome the addiction of technology.

So, country digitalization or technological advancement has high impact on the youth. It is essential for the people to be 'Bhartiya Model of Digital Literacy' based digitally literate which focusses on overall awareness, knowledge, skill, attitude, behavior, understanding of the digital technologies for productive usage; ethically, responsibly, balancing and cyber security [33].

\section{APPENDIX}

\section{A. Questionnaire for the Youth Digital Addiction}

Here, SD-Strongly Disagree, D- Disagree, D/A- Neither Disagree nor Agree, A-Agree and SA- Strongly Agree

\begin{tabular}{|c|c|c|c|c|c|}
\hline Questions & SD & D & D/A & $\mathbf{A}$ & SA \\
\hline \multicolumn{6}{|l|}{$\begin{array}{l}\text { How often do you find that } \\
\text { you stay on-line longer than } \\
\text { you intended? }\end{array}$} \\
\hline \multicolumn{6}{|l|}{$\begin{array}{l}\text { How often do you neglect } \\
\text { household chores to spend } \\
\text { more time on-line? }\end{array}$} \\
\hline \multicolumn{6}{|l|}{$\begin{array}{l}\text { How often do you prefer the } \\
\text { excitement of the Internet to } \\
\text { intimacy with your partner? }\end{array}$} \\
\hline \multicolumn{6}{|l|}{$\begin{array}{l}\text { How often do you form new } \\
\text { relationships with fellow on- } \\
\text { line users? }\end{array}$} \\
\hline \multicolumn{6}{|l|}{$\begin{array}{l}\text { How often do others in your } \\
\text { life complain to you about } \\
\text { the amount of time you } \\
\text { spend on-line? }\end{array}$} \\
\hline \multicolumn{6}{|l|}{$\begin{array}{l}\text { How often do your grades or } \\
\text { school work suffers because } \\
\text { of the amount of time you } \\
\text { spend on-line? }\end{array}$} \\
\hline \multicolumn{6}{|l|}{$\begin{array}{l}\text { How often do you check } \\
\text { your email before something } \\
\text { else that you need to do? }\end{array}$} \\
\hline \multicolumn{6}{|l|}{$\begin{array}{l}\text { How often does your job } \\
\text { performance or productivity } \\
\text { suffer because of the } \\
\text { Internet? }\end{array}$} \\
\hline \multicolumn{6}{|l|}{$\begin{array}{l}\text { How often do you become } \\
\text { defensive or secretive when } \\
\text { anyone asks you what you } \\
\text { do on-line? }\end{array}$} \\
\hline \multicolumn{6}{|l|}{$\begin{array}{l}\text { How often do you block out } \\
\text { disturbing thoughts about } \\
\text { your life with soothing } \\
\text { thoughts of the Internet? }\end{array}$} \\
\hline \multicolumn{6}{|l|}{$\begin{array}{l}\text { How often do you find } \\
\text { yourself anticipating when } \\
\text { you will go on-line again? }\end{array}$} \\
\hline \multicolumn{6}{|l|}{$\begin{array}{l}\text { How often do you fear that } \\
\text { life without the Internet } \\
\text { would be boring, empty, and } \\
\text { joyless? }\end{array}$} \\
\hline \multicolumn{6}{|l|}{$\begin{array}{l}\text { How often do you snap, yell, } \\
\text { or act annoyed if someone } \\
\text { bothers you while you are } \\
\text { on-line? }\end{array}$} \\
\hline How often do you lose sleep & & & & & \\
\hline
\end{tabular}

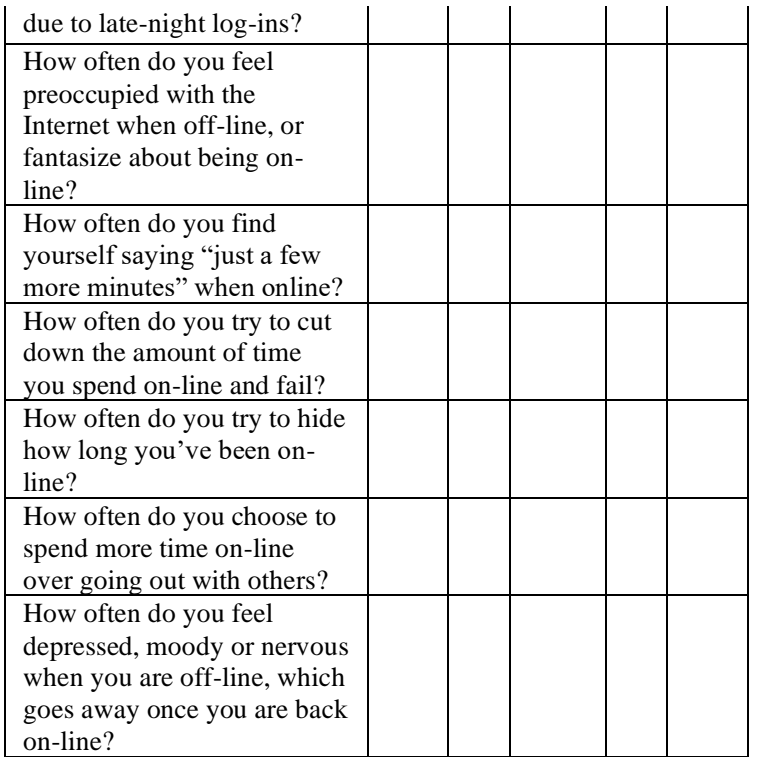

B. Questionnaire for the Adults perception on Digital Addiction of Yotuh

\begin{tabular}{|l|l|l|l|l|l|}
\hline \multicolumn{1}{|c|}{ Questions } & SD & D & D/A & A & SA \\
\hline $\begin{array}{l}\text { You feel that youth stay } \\
\text { online longer than what } \\
\text { they intend? }\end{array}$ & & & & & \\
\hline $\begin{array}{l}\text { You feel that youth } \\
\text { neglect the household's } \\
\text { chores to spend some more } \\
\text { time online. }\end{array}$ & & & & & \\
\hline $\begin{array}{l}\text { You feel that youth prefer } \\
\text { the excitement of the } \\
\text { internet in comparing to } \\
\text { intimacy with their partner. }\end{array}$ & & & & & \\
\hline $\begin{array}{l}\text { You feel that youth form } \\
\text { new relationships with } \\
\text { fellow on-line users? }\end{array}$ & & & & & \\
\hline $\begin{array}{l}\text { You feel that other people } \\
\text { in lives of youth complain } \\
\text { them about the amount of } \\
\text { time they spend online. }\end{array}$ & & & & & \\
\hline $\begin{array}{l}\text { You feel that work suffers } \\
\text { because of the amount of } \\
\text { time spend online by } \\
\text { youth. }\end{array}$ & & & & & \\
\hline $\begin{array}{l}\text { You feel that youth check } \\
\text { their emails before } \\
\text { something else that they } \\
\text { need to do. }\end{array}$ & & & & & \\
\hline $\begin{array}{l}\text { You feel that job } \\
\text { performance or } \\
\text { productivity of youth } \\
\text { suffers because of the } \\
\text { internet. }\end{array}$ & & & & & \\
\hline $\begin{array}{l}\text { You feel that youth } \\
\text { become defensive or } \\
\text { secretive when anyone }\end{array}$ & & & & & \\
\hline $\begin{array}{l}\text { Published By: } \\
\text { Blue Eyes Intelligence Engineering } \\
\& \text { Sciences Publication }\end{array}$ & & & & & \\
\hline
\end{tabular}




\section{The Impact of Technological Advancement on Digital Addiction Level of Youth in India}

asks about their online actions.

You feel that youth block out disturbing thoughts about their life with soothing thoughts of the internet.

You feel that youth find themselves anticipating when they will go online again.

You feel that youth have fear that life without internet would be boring, empty, and joyless.

You feel that youth snap, yell, or act annoyed if someone bothers them while they are online. You feel that youth lose sleep due to late-night logins.

You feel that youth feel preoccupied with the internet when offline, or fantasize about being online.

You feel that youth find themselves saying "just a few more minutes" when online.

You feel that youth try to cut down the amount of time they spend online and fail.

You feel that youth try to hide how long they have been online.

You feel that youth choose to spend more time online over going out with others.

You feel that youth feels depressed, moody or nervous when they are offline, which goes away once they are back online.

\section{REFERENCES}

1. Alghamdi, Y (2016). Negative Effects of Technology on Children of Today. Retrieved from https://www.researchgate.net/publication/318851694_Negative_Effects_ of_Technology_on_Children_of_Today (March, 2016).

2. Bansal, N. (2019). An analysis of various dimensions of ATM Banking Service Quality. International Journal of Management, Accounting and Economics, 6(4), 382-388.

3. Bansal, N., \& Singh, K. (2018). The Impact of Determinants of Service Quality of Automated Teller Machines on Customer Satisfaction. IPE Journal of Management, 8(2), 54-66.
4. Berolo, S., Wells, R. P., \& Amick III, B. C. (2011). Musculoskeletal symptoms among mobile hand-held device users and their relationship to device use: a preliminary study in a Canadian university population. Applied ergonomics, 42(2), 371-378.

5. Chang, R. (2016). Survey: Technology Use Almost Universal for U.S. Children Under https://thejournal.com/articles/2016/10/19/surveytechnology-use-almost-universal-for-children-under-6.aspx last accessed on 30/04/2018.

6. Demirci, K., Akgönül, M., \& Akpinar, A. (2015). Relationship of smartphone use severity with sleep quality, depression, and anxiety in university students. Journal of behavioral addictions, 4(2), 85-92.

7. Ducharme, J. (2017) Kids Are Spending More Time On Mobile Devices Than Ever Before. http://time.com/4989275/young-children-tabletsmobile-devices/ last accessed on 30/04/2018

8. El Asam, A., Samara, M., \& Terry, P. (2019). Problematic internet use and mental health among British children and adolescents. Addictive behaviors, 90, 428-436.

9. Fernandez, O. L., \& Kuss, D. (2019). Harmful internet use-Part I: Internet addiction and problematic use. European Parliamentary Research Service.

10. French M. (2017) Technology May have Negative Social Effect on Kids. http://universe.byu.edu/2017/04/12/technology-may-havenegative-social-effect-on-kids/ last accessed on 30/04/2018.

11. Griffiths, M. (1999). Internet addiction: fact or fiction? The psychologist, 12(5), 246-250.

12. Guze, S. B. (1995). Diagnostic and statistical manual of mental disorders, (DSM-IV). American Journal of Psychiatry, 152(8), 12281228.

13. Hatch, K. E. (2011). Determining the effects of technology on children. Retrieved from https://digitalcommons.uri.edu/cgi/viewcontent.cgi?referer=https://schol ar.google.co.in/\&httpsredir $=1 \&$ article $=1212 \&$ context $=$ srhonorsprog

14. Hosale, S.(2013). 25 Negative effects of technology. RooGirl. Retrieved from http://roogirl.com/25-negative-effects-of-technology/.

15. Jonsson, P., Johnson, P. W., Hagberg, M., \& Forsman, M. (2011). Thumb joint movement and muscular activity during mobile phone texting-A methodological study. Journal of Electromyography and Kinesiology, 21(2), 363-370.

16. Kamemetz, A. (2017). Young Children Are Spending Much More Time In Front Of Screens. https://www.npr.org/sections/ed/2017/10/19/558178851/young-childrenare-spending-much-more-time-in-front-of-small-screens last accessed on 30/04/2018.

17. Khawaja, M. (2012). Technology having bad impact on children's social life: Report. https://arabiangazette.com/technologys-impact-social-lifechildren/ last accessed on 30/04/2018.

18. Kim, Y. (2003). The impact of the Internet on children's daily lives: Physical, social and psychological well-being (Doctoral dissertation, uga). Retrieved from https://getd.libs.uga.edu/pdfs/kim_yeora_200305_phd.pdf

19. Klein, K. M. (2013). Why Don't I Look Like Her? The Impact of Social Media on Female Body Image. https://pdfs.semanticscholar.org/246f/ba670608533ce08b97dcf6cf32b74 18c7762.pdf

20. Kraut, R., Patterson, M., Lundmark, V., Kiesler, S., Mukophadhyay, T., \& Scherlis, W. (1998). Internet paradox: A social technology that reduces social involvement and psychological well-being?. American psychologist, 53(9), 1017.

21. Kwon, M., Lee, J. Y., Won, W. Y., Park, J. W., Min, J. A., Hahn, C., ... \& Kim, D. J. (2013). Development and validation of a smartphone addiction scale (SAS). PloS one, 8(2), e56936.

22. Lei, H., Li, S., Chiu, M. M., \& Lu, M. (2018). Social support and Internet addiction among mainland Chinese teenagers and young adults: A meta-analysis. Computers in Human Behavior, 85, 200-209.

23. Lemola, S., Perkinson-Gloor, N., Brand, S., Dewald-Kaufmann, J. F., \& Grob, A. (2015). Adolescents' electronic media use at night, sleep disturbance, and depressive symptoms in the smartphone age. Journal of youth and adolescence, 44(2), 405-418.

24. Mesch, G. S. (2001). Social relationships and Internet use among adolescents in Israel. Social Science Quarterly, 82(2), 329339.

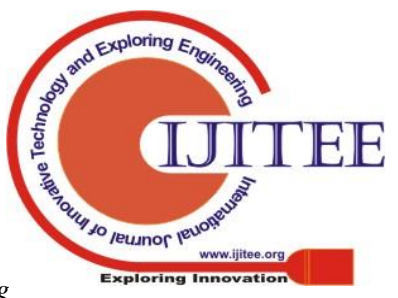


25. Mittal, A. (2019).Women Empowerment through Bhartiya Model of Digital Literacy for New India” Economic Challenger, 21 (82) 71-78.

26. Nie, N. H. (2001). Sociability, interpersonal relations, and the Internet: Reconciling conflicting findings. American behavioral scientist, 45(3), 420-435.

27. Nowland, R., Necka, E. A., \& Cacioppo, J. T. (2018). Loneliness and social internet use: pathways to reconnection in a digital world? Perspectives on Psychological Science, 13(1), 70-87.

28. Ortiz, A. A. (2017) Negative effects of technology on children. https://www.gosanangelo.com/story/life/wellness/2017/04/19/soundmind-negative-effects-technology-children/99872132/ last accessed on 30/04/2018.

29. Perry, T. T., Anne Perry, L., \& Hosack-Curlin, K. (1998). Internet use by university students: an interdisciplinary study on three campuses. Internet Research, 8(2), 136-141.

30. Peterka-Bonetta, J., Sindermann, C., Sha, P., Zhou, M., \& Montag, C. (2019). The relationship between Internet Use Disorder, depression and burnout among Chinese and German college students. Addictive behaviors, 89, 188-199.

31. Pickerill, M. (2015). Raising The Screen Generation. http:/time.com/raising-the-screen-generation/ last accessed on 30/04/2018.

32. Purohit H, Bhattacharya B., Bindra P. (2019), Need of Digital Literacy and E-Content Crisis Management in India: A Study from the Bharatiya Perspectives, International Journal of Innovative Technology and Exploring Engineering (IJITEE) Volume-8 Issue-6C

33. Purohit, H., Bharti, N., \& Joshi, A. (2015). Partnering for Promotion of Digital Literacy among Women in Rajasthan through Bhartiya Model of Digital Literacy. Available at SSRN 2665736.

34. Shaw, M., \& Black, D. W. (2008). Internet addiction. CNS drugs, 22(5), 353-365.

35. Singh, P. J., \& Mittal, A. (2017). Demonetization: A Step Towards Digitalization of Consumers. International Journal of Engineering Technology, Management and Applied Sciences, 5(3), 434-437.

36. Soh, P. C. H., Chew, K. W., Koay, K. Y., \& Ang, P. H. (2018). Parents vs peers' influence on teenagers' Internet addiction and risky online activities. Telematics and Informatics, 35(1), 225-236.

37. Trudeau, M. B., Young, J. G., Jindrich, D. L., \& Dennerlein, J. T. (2012). Thumb motor performance varies with thumb and wrist posture during single-handed mobile phone use. Journal of biomechanics, 45(14), 2349-2354.

38. Young, K. S. (1998). Internet addiction: The emergence of a new clinical disorder. Cyberpsychology \& behavior, 1(3), 237-244.

39. Young, K. S., \& Rogers, R. C. (1998). The relationship between depression and Internet addiction. Cyberpsychology \& behavior, 1(1), 25-28.

40. Zheng, S., Guan, W., Li, B., \& Qin, D. Z. (2015, December). Social Work in Teen Addiction Correction Services Research under the New Situation. In 2015 4th National Conference on Electrical, Electronics and Computer Engineering. Atlantis Press

\section{AUTHORS PROFILE}

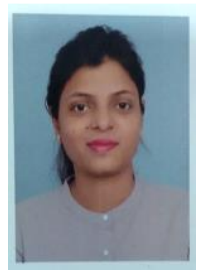

Dr. Aditi Mittal is a Research Associate at the Department of State Bank of India School of Commerce and Banking, Banasthali Vidyapith. Recently, she has completed her Doctorate on the topic "Application of Bhartiya Model of Digital Literacy on Women Empowerment in selected districts of Rajasthan". She has presented multiple papers in the International and National Conferences and also attended many Faculty Development Programmes (FDP's) at various places. She has published her research papers in journals like Economic Challenger, International Journal of Engineering Technology, Management and Applied Sciences etc.

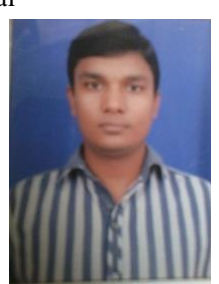

Mr. Nitin Bansal had completed his Post Graduation in Business Management (MBA) from Department of Management, Kurukshetra University, Kurukshetra, Haryana in 2008 and now pursuing Ph.D from FMS WISDOM, Banasthali Vidyapith, Jaipur, India on the topic "The Impact of Paper Less Currency on Banking Sector of India and its acceptability by customers: An Analytical Study of Uttar Pradesh". He is having total 11 years of experience including banking industry and academia. In 2018, he has been appointed as an external trainer in State Bank of India. He has published multiple papers in various international and national journals including ABDC Listed journals, Scopus indexed journals and Thomson Reuters indexed journals. 